\title{
SPECIATION OF IRON, ZINC, LEAD AND CALCIUM IN BLAST FURNACE TOP-GAS FILTER DUST BY SEQUENTIAL LEACHING
}

\author{
${ }^{1}$ Christof LANZERSTORFER \\ ${ }^{1}$ University of Applied Sciences Upper Austria,Wels, Austria, EU, c.lanzerstorfer@fh-wels.at
}

https://doi.org/10.37904/metal.2021.4072

\begin{abstract}
Top-gas dedusting at blast furnaces $(\mathrm{BF})$ is usually done with venturi scrubbers. However, in recent years, the total dry dedusting of BF top-gas has become a common technology. In this case, a fabric filter is used instead of the venturi scrubber. For recycling, the dry dust from a fabric filter is preferable to the sludge from a scrubber. The main constituents of $\mathrm{BF}$ dedusting residues, $\mathrm{Fe}, \mathrm{C}$ and $\mathrm{Ca}$ are of some value, while tramp elements, particularly $\mathrm{Zn}$, can cause problems in the process. Results from leaching of the sludge obtained in wet BF dedusting are available. In contrast, data from leaching of dry filter dust from BF dedusting are not available. However, it has to be assumed that the behavior of a dust from dry dedusting deviates somewhat from that of a sludge due to the prolonged residence time of the sludge in the scrubber system under varying $\mathrm{pH}$. In this study the filter dust of a BF top-gas dry dedusting filter was investigated, applying sequential leaching and Xray diffraction analysis for the investigation of the distribution of $\mathrm{Fe}, \mathrm{Ca}, \mathrm{Zn}$ and $\mathrm{Pb}$ in various compounds with a focus on the tramp element $Z n$.
\end{abstract}

Keywords: Blast furnace, filter dust, zinc, leaching

\section{INTRODUCTION}

In an integrated steel mill the dedusting system for the blast furnace (BF) top-gas normally consists of two stages, a dry pre-separator (dust catcher or cyclone) as the first stage and a venturi scrubber for the final dedusting [1]. In recent years, the total dry dedusting of the top-gas has become a common technology [2-4]. In this case, a fabric filter is used in the second dedusting stage instead of the venturi scrubber. Thereby, the BF sludge from the scrubber system is replaced by dry dust, which facilitates handling of the residue. The main constituents of the $\mathrm{BF}$ dedusting residues, $\mathrm{Fe}, \mathrm{C}$ and $\mathrm{Ca}$ are of some value, which supports recycling, e.g. via the sinter plant $[5,6]$. However, some tramp elements, particularly $\mathrm{Zn}$, are limited in the recycling stream, as they can cause operational problems in the BF. Zn contained in the BF charge is easily reduced to metallic $\mathrm{Zn}$ and volatilized when the material moves downwards in the shaft and reaches a temperature higher than $1173 \mathrm{~K}$ [7]. The $\mathrm{Zn}$ vapour moves upwards with the gas stream and at lower temperature the $\mathrm{Zn}$ is re-oxidized forming fine particles, which are partly discharged with the top-gas.

The leaching of $\mathrm{Zn}$ from the dust separated in the first dedusting stage (BF dust) has been investigated [8-10]. There is also some information available on the distribution of $Z n$ in this dust. X-ray diffraction patterns of such dusts show that beside $\mathrm{ZnO}$ [9-12] and $\mathrm{ZnFe}_{2} \mathrm{O}_{4}[9,10]$ it also containes $\mathrm{ZnS}$ [11,12] and $\mathrm{ZnCO}_{3}$ [12]. In contrast to the $\mathrm{Zn}$ concentration in the dust from the first dedusting stage the $\mathrm{Zn}$ concentration in the residue from the second dedusting stage is usually considerably higher $[1,13]$ Likewise, leaching of the sludge obtained in wet second-stage dedusting (BF sludge) was also investigated [14-18]. In the BF sludge $\mathrm{Zn}$ is found as $\mathrm{ZnO}$ [15] and as $\mathrm{ZnFe}_{2} \mathrm{O}_{4}[16,17]$.

For the dust from a second stage dry dedusting system (BF filter dus) it is likely that the composition deviates somewhat from that of a BF sludge as well as from a BF dust. In comparison to the BF dust, the particle size of the BF filter dust separated in the second dedusting stage is smaller and the concentrations of the tramp 
elements are higher. Due to the prolonged residence time of the BF sludge in the scrubber water system under varying $\mathrm{pH}$ conditions, the composition may change and therefore be different to the $\mathrm{BF}$ filter dust.

In this study the BF filter dust from a second-stage dry dedusting filter for BF top-gas dedusting was investigated for the distribution of $\mathrm{Fe}, \mathrm{Ca}, \mathrm{Zn}$ and $\mathrm{Pb}$ in various compounds, with a focus on the tramp element $\mathrm{Zn}$.

\section{MATERIALS AND METHODS}

The BF filter dust sample was obtained from the dust discharge of the second-stage dedusting filter of an industrial BF top-gas cleaning system. Detailed information on the dust sample has been published previously [19].

The leaching experiment was carried out in a sequence of five steps, the residue being treated from a leaching step in the next step. The leaching process was adapted from a leaching procedure for BOF dust [20]. In the first step, the exchangeable, slightly water-soluble fraction (L1) was extracted. In the subsequent steps, the carbonated fraction (L2), the oxides (L3), the reduced fraction (L4) and the residual fraction (L5) were obtained. Details of the leaching process can be found elsewhere [21]. An ICP-OES system (iCAP 7000 Plus Series) was used to measure the concentrations of $\mathrm{Fe}, \mathrm{Ca}, \mathrm{Zn}$ and $\mathrm{Pb}$ in the leachates.

Microscopic images of the BF filter dust were produced with a scanning electron microscope TESCAN, type VEGA LM.

For $\mathrm{Zn}$ and $\mathrm{Pb}$ the thermodynamic equilibrium composition under $\mathrm{BF}$ top-gas conditions $\left(50 \% \mathrm{~N}_{2}, 25 \% \mathrm{CO}\right.$, $23 \% \mathrm{CO}_{2}$ and $2 \% \mathrm{H}_{2} \mathrm{O}$ by volume) was calculated as a function of the temperature using the HSC Chemistry 8.1 program.

\section{RESULTS AND DISCUSSIONS}

The concentrations of $\mathrm{Fe}, \mathrm{Ca}, \mathrm{Zn}$ and $\mathrm{Pb}$ in the dust were $13.6 \%, 5.2 \%, 1.88 \%$ and $0.29 \%$, respectively. Figure 1 shows a microscope image of the BF dust.

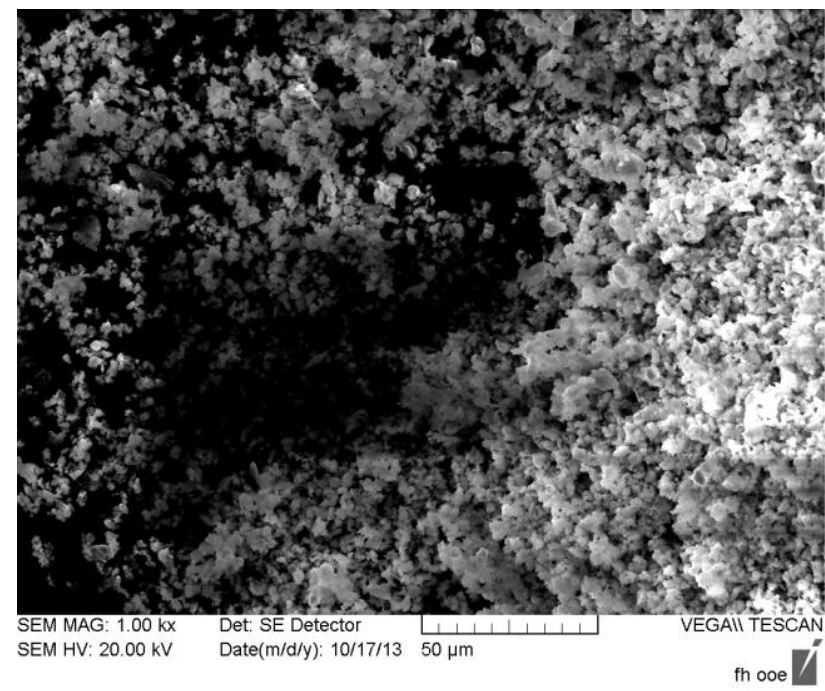

Figure 1 Microscope image of the BF dust

The results of the sequential leaching test are shown in Figure 2. Fe was found mainly in the residual fraction $(81 \%)$ and to a lesser extent in the carbonated fraction. This corresponds to reported qualitative data [16]. In 
contrast, Ca was found in all fractions L1 to L4 to a noticeable extent with two thirds of the amount in L1 and L2 to approximately similar parts.

$\mathrm{Zn}$ was found mainly in the carbonate fraction $(60 \%)$ and in the oxide fraction $(27 \%)$, while a lower amount of $\mathrm{Zn}$ was found in the reduced fraction (11\%). The amount in the residual fraction was $3 \%$, indicating that the amount of $\mathrm{ZnFe}_{2} \mathrm{O}_{4}$ in the dust was small. The distribution of $\mathrm{Zn}$ in the $\mathrm{BF}$ filter dust is therefore more similar to that in the BF dust [9-12] than to the distribution in BF sludge [15-17].

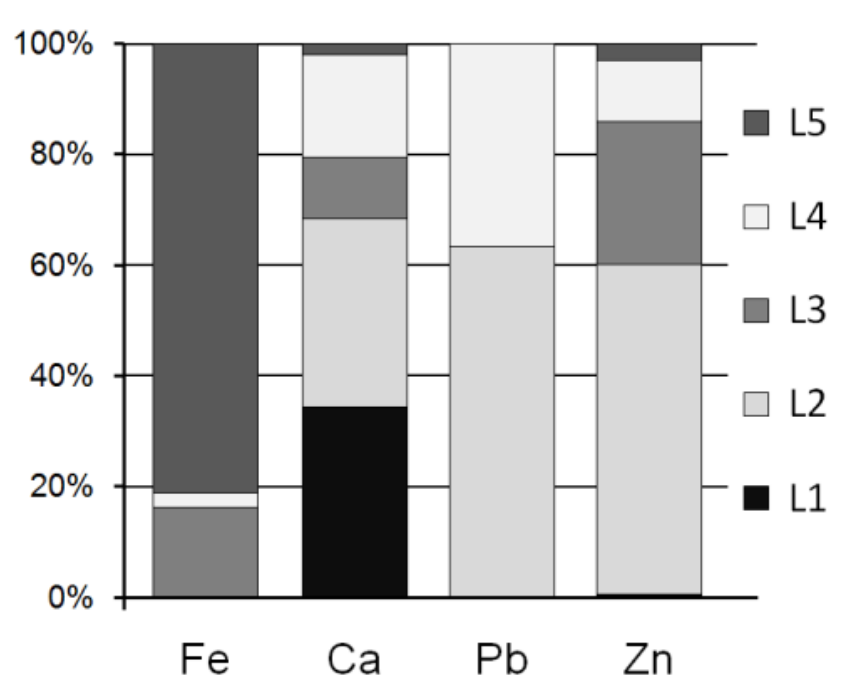

Figure $2 \mathrm{Fe}, \mathrm{Ca}, \mathrm{Pb}$ and $\mathrm{Zn}$ in various fractions

The results of the thermodynamic equilibrium calculations for the distribution of $\mathrm{Zn}$ as a function of the temperature are shown in Figure 3.

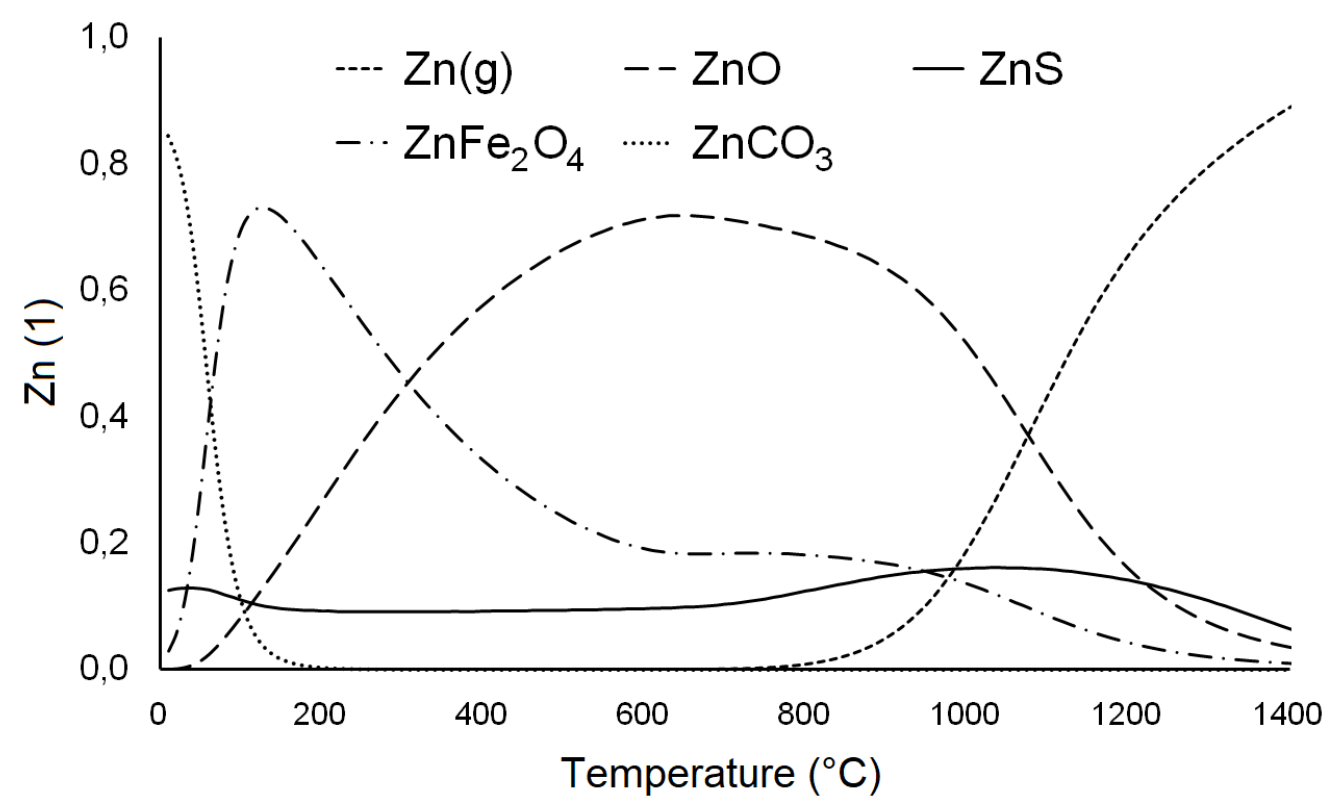

Figure 3 Distribution of $\mathrm{Zn}$ at thermodynamic equilibrium

In the high temperature zone of the $\mathrm{BF}$, most $\mathrm{Zn}$ is present as metallic $\mathrm{Zn}(\mathrm{g})$ while some $\mathrm{ZnS}$ also exists. Solid $\mathrm{ZnO}$ and $\mathrm{ZnFe}_{2} \mathrm{O}_{4}$ are formed when the gas temperature decreases. Below $600^{\circ} \mathrm{C}$ the $\mathrm{ZnO}$ concentration decreases because of the formation of $\mathrm{ZnFe}_{2} \mathrm{O}_{4}$. The comparatively small amount of $\mathrm{ZnFe}_{2} \mathrm{O}_{4}$ found in the leaching experiments might be due to the fact that reaction rates in solid reactions are low. When the dust and 
the $\mathrm{ZnO}$ particles are separated by the fabric filter, a filter cake is formed on the filter cloth and the top-gas containing $\mathrm{CO}_{2}$ passes through this filter cake for some time before the filter cake is removed in the pulse-jet cleaning cycle. During this period of time the reaction of $\mathrm{ZnO}$ with $\mathrm{CO}_{2}$ to $\mathrm{ZnCO}_{3}$ might occur.

$\mathrm{Pb}$ was found only in the carbonate fraction (63\%) and in the reduced fraction. This finding agrees well with the results of the equilibrium calculations shown in Figure 4. At a temperature above $1000^{\circ} \mathrm{C}$, gaseous $\mathrm{Pb}(\mathrm{g})$ and $\mathrm{PbS}(\mathrm{g})$ exist parallel to $\mathrm{PbO}$, while below these temperatures the stable form is $\mathrm{PbO}$. At temperatures below $400^{\circ} \mathrm{C}$ the equilibrium gradually shifts to $\mathrm{PbS}$. Below $200^{\circ} \mathrm{C} \mathrm{PbCO}_{3}$ is also formed. In the fabric filter the formation of $\mathrm{PbCO}_{3}$ can take place in a similar way, as explained previously for $\mathrm{ZnCO}_{3}$.

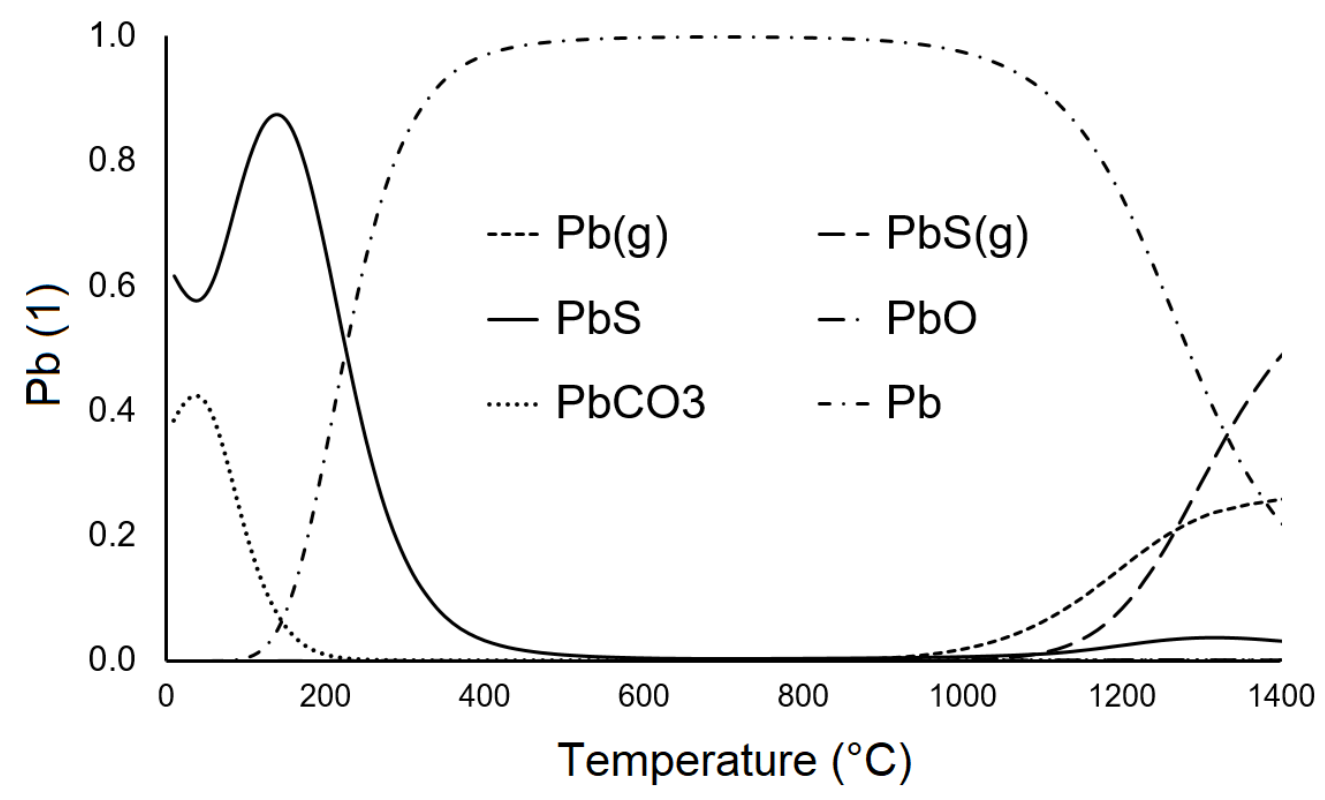

Figure 4 Distribution of $\mathrm{Pb}$ at thermodynamic equilibrium

\section{CONCLUSIONS}

In the BF filter dust from second-stage BF dedusting Fe was found mainly in the residual fraction and Ca was found mainly in the exchangeable fraction and the carbonated fraction to approximately similar parts. The tramp element $\mathrm{Zn}$ is mainly present in the carbonate fraction, in the oxidic fraction and in the reduced fraction. In contrast, $\mathrm{Pb}$ is present in the carbonate fraction and in the reduced fraction. The deviations between the measurement results and the results of the thermodynamic equilibrium calculations can be explained by taking into account the conditions in the gas cleaning system. With respect to the distribution of $\mathrm{Zn}$, the BF filter dust obtained in dry second stage dedusting is more similar to the BF dust from first stage dedusting than to the BF sludge obtained in wet second stage dedusting.

\section{ACKNOWLEDGEMENTS}

The study was financially supported by K1-MET. K1-MET is a member of COMET - Competence Centers for Excellent Technologies and is financially supported by the BMVIT (Federal Ministry for Transport, Innovation and Technology), BMWFJ (Federal Ministry of Economy, Family and Youth), the federal states of Upper Austria, Styria and Tyrol, SFG and Tiroler Zukunftsstiftung. COMET is managed by FFG (Austrian research promotion agency). Preparation of scanning electron microscope images by M. Gillich, laboratory work by K.F. Dale and proofreading by P. Orgill is gratefully acknowledged. 


\section{REFERENCES}

[1] REMUS, R., AGUADO-MONSONET, M.A., ROUDIER, S., SANCHO, L.D. Best Available Techniques (BAT) Reference Document for Iron and Steel Production, Industrial Emissions Directive 2010/75/EU, Integrated Pollution Prevention and Control. Luxembourg: Publications Office of the European Union, 2013.

[2] ZHANG, F.-M. Study on Dry Type Bag Filter Cleaning Technology of BF Gas at Large Blast Furnace. In: Proceedings of the 5th International Congress on the Science and Technology of Ironmaking (ICSTI'09). Shanghai: The Chinese Society for Metals, 2009, pp. 608-612.

[3] LANZERSTORFER, C., XU, Q. Neue Entwicklungen zur Gichtgasreinigung von Hochöfen: ein Überblick. Bergund Hüttenmännische Monatshefte. [online]. 2014, vol. 159, no. 3, pp. 91-98. Available from: https://doi.org/10.1007/s00501-013-0145-9.

[4] KLUGSBERGER, A. Advanced top-gas cleaning for blast furnaces - cleaner and cheaper dust capture. Metals Magazine. 2012, vol. 7, no. 1, pp. 28-30.

[5] YEHIA, A., EL-RAHIEM, F.H. Recovery and utilization of iron and carbon values from blast furnace flue dust. Mineral Processing and Extractive Metallurgy. [online]. 2005, vol. 114, no. 4, pp. 207-211. Available from: https://doi.org/10.1179/037195505X28519.

[6] LANZERSTORFER, C., BAMBERGER-STRASSMAYR, B., PILZ, K. Recycling of blast furnace dust in the iron ore sinter process: investigation of coke breeze substitution and the influence on off-gas emissions. ISIJ International. [online]. 2015, vol. 55, no. 4, pp. 758-764. Available from: https://doi.org/10.2355/isijinternational.55.758.

[7] ESEZOBOR, D.E., S. BALOGUN, S.A. Zinc accumulation during recycling of iron oxide wastes in the blast furnace. Ironmaking and Steelmaking. [online]. 2006, vol. 33, no. 5, pp. 419-425. Available from: https://doi.org/10.1179/174328106X114020.

[8] ZEYDABADI, B.A., MOWLA, D., SHARIAT, M.H., KALAJYHI, J.F. Zinc recovery from blast furnace flue dust. Hydrometallurgy. 1997, vol. 47, no. 1, pp. 113-125.

[9] ZHANG, D., ZHANG, X., YANG, T., RAO, S., HU, W., LIU, W., CHEN, L. Selective leaching of zinc from blast furnace dust with mono-ligand and mixed-ligand complex leaching systems. Hydrometallurgy. [online]. 2017, vol. 169, pp. 219-228. Available from: https://doi.org/10.1016/j.hydromet.2017.02.003.

[10] MA, A., ZHENG, X., ZHANG, L., PENG, J., LI, Z., LI, S., LI, S. Clean recycling of zinc from blast furnace dust with ammonium acetate as complexing agents, Separation Science and Technology. [online]. 2018, vol. 53, no. 9, pp. 1327-1341. Available from: https://doi.org/10.1080/01496395.2018.1444057.

[11] SELIVANOV, E.N., TYUSHNYAKOV, S.N., PANKRATOV, A.A. Forma of zinc occurrence in blast-furnace dust. Metallurgist. [online]. 2018, vol. 62, no. 3-4, pp. 225-230. Available from: https://doi.org/10.1007/s11015-018$\underline{0649-3}$

[12] SALEH, H.I., HASSAN, K.M. Extraction of zinc from blast-furnace dust using ammonium sulfate. Journal of Chemical Technology and Biotechnology. [online]. 2004, vol. 79, no. 4, pp. 397-402. Available from: https://doi.org/10.1002/jctb.996.

[13] ANDERSSON, A., GULLBERG, A., KULLERSTEDT, A., SANDBERG, E., ANDERSSON, M., AHMED, H., SUNDQVIST-ÖKVIST, L., BJÖRKMAN, B. A Holistic and Experimentally-Based View on Recycling of Off-Gas Dust within the Integrated Steel Plant. Metals. [online]. 2018, vol. 8, no. 10, 760. Available from: https://doi.org/10.3390/met8100760.

[14] VAN HERCK, P., VANDESACTEELE, C., SWENNEN, R., MORTIER, R. Zinc and Lead Removal from Blast Furnace Sludge with a Hydrometallurgical Process. Environmental Science and Technology. [online]. 2000, vol. 34, no. 17, pp. 3802-3808. Available from: https://doi.org/10.1021/es991033l.

[15] STEER, J.M., GRIFFITHS, A.J. Investigation of carboxylic acids and non-aqueous solvents for the selective leaching of zinc from blast furnace dust slurry. Hydrometallurgy. [online]. 2013, vol.140, pp. 34-41. Available from: https://doi.org/10.1016/i.hydromet.2013.08.011.

[16] VEREŠ, J., LOVĂS, M., JAKABSKY், Š., ŠEPELĂK, V., HREDZĂK, S. Characterization of blast furnace sludge and removal of zinc by microwave assisted extraction. Hydrometallurgy. [online]. 2012, vol. 129-130, pp. 67-73. Available from: $\underline{\text { https://doi.org/10.1016/j.hydromet.2012.09.008. }}$ 
[17] SORIA-AGUILAR, M., DAVILA-PULIDO, G.I., CARRILLO-PEDROZA, F.R., GONZALEZ-IBARRA, A.A., PICAZORODRIGUEZ, N., LOPEZ-SAUCEDO, F., RAMOS-CANO, J. Oxidative Leaching of Zinc and Alkalis from Iron Blast Furnace Sludge. Metals. [online]. 2019, vol. 9, no. 9, p. 1015. Available from:

https://doi.org/10.3390/met9091015.

[18] TRINKEL, V., MALLOW, O., ASCHENBRENNNER, P., RECHBERGER, H., FELLNER, J. Characterization of Blast Furnace Sludge with Respect to Heavy Metal Distribution. Industrial and Engineering Chemical Research. [online]. 2016, vol. 55, pp. 5590-5597. Available from: https://doi.org/10.1021/acs.iecr.6b00617.

[19] LANZERSTORFER, C., KRÖPPL, M. Air classification of blast furnace dust collected in a fabric filter for recycling to the sinter process. Resources, Conservation and Recycling. [online]. 2014, vol. 86, pp. 132-137. Available from: https://doi.org/10.1016/..resconrec.2014.02.010.

[20] SAMMUT, M.L., ROSE, J., MASION, A., FIANI, E., DEPOUX, M., ZIEBEL, A., HAZEMANN, J.L., PROUX, O., BORSCHENK, D., NOACK, Y. Determination of zinc speciation in basic oxygen furnace flying dust by chemical extractions and X-ray spectroscopy. Chemosphere. [online]. 2008, vol. 70, no. 11, pp. 1945-1951. Available from: https://doi.org/10.1016/j.chemosphere.2007.09.063.

[21] LANZERSTORFER, C., PREITSCHOPF, W. Steelmaking Dust: Speciation of Zinc by Sequential Leaching. Inżynieria Mineralna. [online]. 2020, vol. 45, no. 1-2, pp. 79-82. Available from: https://doi.org/10.29227/IM-2020$\underline{01-44}$. 